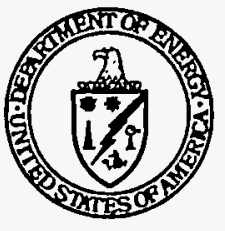

\title{
Regulatory Requirements Affecting Disposal of Asbestos-Containing Waste
}

BACKGROUND; Many U.S. Department of Energy (DOE) facilities are undergoing decontamination and decommissioning (D\&D) activities. The performance of these activities may generate asbestos-containing waste because asbestos was formerly used in many building materials, including floor tile, sealants, plastics, cement pipe, cement sheets, insulating boards, and insulating cements. The regulatory requirements governing the disposal of these wastes depend on: 1) the percentage of asbestos in the waste and whether the waste is friable (easily crumbled or pulverized); 2) other physical and chemical characteristics of the waste; and 3) the State in which the waste is generated. This Information Brief provides an overview of the environmental regulatory requirements affecting disposal of asbestos-containing waste. It does not address regulatory requirements applicable to worker protection promulgated under the Occupational Safety and Health Act (OSHAct), the Mining Safety and Health Act (MSHA), or the Toxic Substances Control Act (TSCA).

STATUTES: Clean Air Act (CAA), Resource Conservation and Recovery ACt (RCRA), and TSCA.

REGULATIONS: 40 GFR 61, Subpart M, National Emission Standard for Asbestos; 40 CFR 241, Guidelines for the Land Disposal of Solid Wastes; 40 CFR 257, Criteria for Classification of Solid Waste Disposal Facilities and Practices; 40 CFR 763, Subpart D, Reporting Commercial and Industrial Uses of Asbestos: 40 CFR 763, Appendix $C$ to Subpart $E_{y}$ Asbestos Model Accreditation Plan; and 22 California Code of Regulations (CCR), Chapter 11, Article 3, Characteristics of Hazardous Waste, Section 66261.24, Characteristic of Toxicity.

REFERENCES: 1. Corrective Action for Solid Waste Management Units at Hazardous Waste Management Facilities, Proposed Rule (55 ER 30798 et seq;; July 27, 1990).

2. Land Disposal Restrictions for Newly Listed Wastes and Contaminated Debris, Proposed Rule (57 EB 993-994; January 9, 1992).

3. Lañd Disposal Restrictions for Newly Listed Wastes and Contaminated Debris, Final Rule (57 ER 37238-37239; August 18, 1992).

What regulatory requirements apply to disposal of asbestos and asbestos-containing waste?

Regulatory requirements applicable to the disposal of asbestos and asbestos-containing waste from asbestos milling, manufacturing, fabricating, demolition, renovation, air cleaning, and spraying operations are located in Subpart $M$ of 40 CFR 61, National Emission Standards for Hazardous Air Pollutants (NESHAPs). The asbestos-containing wastes subject to the standard include mill tailings or any waste that contains commercial asbestos and is generated by a source subject to Subpart M of 40 CFR 61 . These wastes include filters from control devices, friable asbestos waste material, and bags or other similar packaging material contaminated with commercial asbestos.
The regulatory requirements applicable to different types of asbestos operations vary according to the type of asbestos waste that is generated. These types of waste are defined below.

Friable asbestos material is defined as any material containing more than 1 percent asbestos that, when dry, can be crumbled, pulverized, or reduced to powder by hand pressure.

Nonfriable asbestos-containing material is defined as any material containing more than 1 percent asbestos that, when dry, cannot be crumbled, pulverized, or reduced to powder by hand pressure. 
D Category I nonfriable asbestos-containing material is defined as asbestos-containing packings, gaskets, resilient floor covering, and asphalt roofing products containing more than 1 .percent asbestos.

Category II nonfriable asbestos-containing material is defined as any material, excluding Category I nonfriable asbestos-containing material, containing more than 1 percent asbestos that, when dry, cannot be crumbled, pulverized, or reduced to powder by hand pressure.

Regulated asbestos-containing material is defined as friable asbestos material; Category I nonfriable asbestoscontaining material that has become friable; Category I nonfriable asbestos-containing material that will be or has been subjected to sanding, grinding, cutting or abrading; and Category II nonfriable asbestos-containing material that has a high probability of becoming or has become crumbled, pulverized, or reduced to powder by the forces expected to act on the material in the course of demolition or renovation operations.

- Asbestos-containing waste materials are defined as regulated asbestos-containing material waste and materials contaminated with asbestos during demolition and renovation operations, including disposable equipment and clothing.

\section{What other regulatory programs address asbestos waste?}

Other regulatory programs addressing asbestos waste are listed below.

Regulations promulgated under Subtitle D of the Resource Conservation and Recovery Act (RCRA) contain criteria that are applicable to asbestos disposal sites if they are also solid waste landfills [40 CFR 241 and 257].

Regulations promulgated under the Toxic Substances Control Act (TSCA) ban the manufacture and distribution of,.impose labeling requirements on, and require the disposal of certain asbestos-containing products [ $40 \mathrm{CFR}$ 763, Subpart D].

$\square$ Regulations promulgated under the Asbestos School Hazard Abatement Reauthorization Act require accreditation of persons who inspect for asbestos-containing material in school, public, and commercial buildings; and accreditation of persons who design or conduct response actions with respect to friable asbestos-containing material in such buildings. Public buildings are defined to include government-owned buildings [ 40 CFR 63, Appendix $C$ to Subpart E - Asbestos Model Accreditation Plan].

Regulations promulgated under TSCA, the Occupational Safety and Health Act (OSHAct), and the Mine Safety and Health Act (MSHA) contain requirements applicable to worker protection during the generation and disposal of asbestos waste.
Federal regulations promulgated under Subtitle C of RCRA (pertaining to hazardous waste) do not address asbestoscontaining wastes. Proposed corrective action regulations, however, include an action level for asbestos, even though asbestos is not listed as a hazardous waste constituent in Appendix VIII to 40 CFR 261 or as a hazardous constituent in groundwater in Appendix IX to 40 CFR 264 (see Reference 1).

\section{What types of 40 CFR 61, Subpart M standard's apply to disposal of asbestos-containing waste generated from D\&D activities?}

Regulations under 40 CFR 61.150 require owners/operators of demolition operations to discharge no visible emissions to the outside air during the collection, processing (including incineration), packaging, or transporting of any asbestos-containing waste material, or to use one of the following emissions control and waste treatment methods: adequately wet asbestos-containing waste material [40 CFR 61.150 (a)(1)(i)-(iv) or 40 CFR 61.150 (a)(3)], process asbestos-containing waste material into nonfriable forms [40 CFR 61.150 (a)(2)(i)-(ii)], or employ an alternative emission control and waste treatment method that has received prior EPA approval [40 CFR 61.150 (a)(4)]. (These requirements are not applicable to nonfriable asbestos-containing material waste [40 CFR 61.150(a)(5)].)

As soon as is practical, the waste generator must deposit asbestos-containing waste material at a waste disposal site operated in accordance with the provisions of 40 CFR 61.154 , or a U.S. Environmental Protection Agency (EPA)approved site that converts regulated asbestos-containing material and asbestos containing waste material into nonasbestos material in accordance with 40 CFR 61.155 [ 40 CFR 61.150.(b)(1)-(2)]. (This provision is not applicable to Category I nonfriable asbestos-containing material that is not regulated asbestos-containing material.)

The waste generator is required to maintain waste shipment records for all asbestos-containing waste material that is transported offsite, provide a copy of the waste shipment record to disposal site owners or operators, report the failure of asbestos waste shipments to reach designated waste disposal sites, and retain copies of waste shipment records for at least 2 years [40 CFR 61.150 (d)(1)-(5)].

What standards are applicable to DOE sites disposing of asbestos-containing materials onsite?

DOE sites disposing of asbestos-containing materials onsite must meet 40 CFR 61.154 standards for active waste disposal sites. These standards require that:

there be no visible emissions to the outside air from any active waste disposal site where asbestos-containing waste material has been deposited [40 CFR 61.154(a)]; or 
the asbestos containing waste material be covered at the end of each operating day, or at least once every 24-hour period while the site is in continuous operation, with either 6 inches of compacted nonasbestos-containing material or a resinous or petroleum-based dust suppression agent that effectively binds dust and controls wind erosion [40 CFR 61.154(c)]; or

an alternative emissions control measure that has received prior EPA approval be implemented [40 CFR 61.154(d)].

Active waste disposal sites must also meet requirements regarding warning signs and fencing [40 CFR 61.154(b)(1)(3)], recordkeeping, and closure [40 CFR 61.154(e)].

\section{What regulatory requirements are applicable to the disposal of asbestos-containing wastes that are also hazardous wastes?}

Asbestos-containing wastes may also be hazardous wastes if they are located in a State that regulates asbestos under RCRA or if they are contaminated with a listed waste or exhibit a characteristic of hazardous waste. Chromiumcontaminated asbestos pipe and insulation is hazardous, for example, if it fails the toxicity characteristic leaching procedure.

Asbestos-containing wastes that are also hazardous wastes must be handled in accordance with applicable RCRA and 40 CFR 61, Subpart $M$ requirements. Asbestos-containing "hazardous waste would often be subject to RCRA land disposal restriction treatment standards for debris. However, many of the recommended treatment technologies for hazardous debris (such as abrasive blasting, electropolishing, scarification and grinding, and spalling) are not recommended for the treatment of asbestos-containing hazardous debris, because their use would cause increased potential for occupational exposure or environmental release of asbestos. For this reason, EPA suggests that the following technologies, using filtration devices on air and water emissions to control asbestos, be used to treat asbestos-containing hazardous debris in compliance with applicable Occupational Safety and Health Act, NESHAPs, and TSCA standards: water washing and spraying, liquid phase solvent extraction, biodegradation, chemical oxidation, chemical reduction, and macroencapsulation. EPA also states that if bagging meets the performance standard for macroencapsulation, such debris may then be disposed of in a RCRA Subtitle C facility (see References 2 and 3).
Which States regulate asbestos-containing wastes as hazardous waste?

Only the State of California regulates asbestos-containing wastes as hazardous waste. Waste containing 1.0 percent or more asbestos by weight is regulated in California as hazardous waste for exhibiting the characteristic of toxicity, if the asbestos is friable [22 CCR, Chapter 11, Article 3, Characteristics of Hazardous Waste, Section 66261.24, Characteristic of Toxicity].

\section{What additional requirements are applicable to asbestos-containing wastes that are radioactive or contain polychlorinated biphenyls (PCBs)?}

Asbestos-containing wastes that are also radioactive must also be disposed of in accordance with the requirements of DOE Order 5820.2A, Radioactive Waste Management. If these wastes contain PCBs, they must also be disposed of in accordance with regulations promulgated by EPA on the disposal of PCBs [40 CFR 761].

\section{Where are DOE sites disposing of asbestos wastes?}

Fernald began shipping low-level radioactive, nonfriable asbestos waste to the Nevada Test Site in 1994. The Savannah River Site, Los Alamos National Laboratory, and other DOE sites dispose of nonradioactive and low-level radioactive asbestos wastes onsite.

\section{How does the presence of asbestos in D\&D waste affect the ability of DOE to recycle these wastes?}

Due to the TSCA ban on the manufacture and distribution in commerce of new uses of asbestos [40 CFR 763.165(a)], the presence of asbestos in D\&D waste renders this waste nonrecyclable. Consequently, DOE sites should segregate asbestos-containing wastes from other D\&D wastes if these wastes could otherwise be recycled.

Questions of policy or questions requiting policy decisions will not be dealt with in EH-413 Information Briefs unless thatpplicy hàs already been established through appropriate documentation. Please refer any questions concerning the subject material covered in this Information Brief to Beverly Whitehead, RCRA/CERCLA Division, EH-413, (202)586-6073. 
Reisa Kall (EH-413)

U.S. Department of Energy

1000 Independence Avenue, S.W.

Washington, D.C. 20585

ADDRESS CORRECTION REQUESTED 